\title{
KATECHEZA MARYJNA DZIECI I MŁODZIEŻY SZKOLNEJ. ŹRÓDŁA, ZAKRESY TEMATYCZNE, ZASADY
}

Rok 2017 był rokiem wielkich rocznic maryjnych. Na pierwszy plan wysuwa się stulecie objawień fatimskich, tak mocno odnoszących się do współczesności, stanowiących wyzwanie dla refleksji teologicznej, duszpasterstwa i katechezy oraz pobożności katolików. W Polsce świętowano też kilka rocznic, z których chyba najważniejszą była 300. rocznica koronacji Obrazu Jasnogórskiego. $\mathrm{Na}$ to wszystko nakładało się świętowanie przez wspólnoty protestanckie 500. rocznicy wystąpienia Marcina Lutra, które uznaje się za symboliczny początek reformacji, co dla tematyki maryjnej ma, oczywiście, niemałe znaczenie. Dobrze zatem się stało, że w Polsce kontekst maryjny, zwykle doceniany w praktyce kościelnej, doczekał się szczególnej refleksji teologicznej.

Celem niniejszego artykułu jest ukazanie głównych wyzwań, przed którymi stoi polska katecheza, także nauczanie religii w szkole; wyzwania te odnoszą się do właściwego ujęcia osoby Matki Boga w przeżywaniu i praktykowaniu katolicyzmu, a także do tematyki, która jest konieczna, by docenić element ewangelizacyjny i tożsamościowy w przepowiadaniu wiary. Kolejno zatem podejmę zagadnienie relacji trzech pojęć: katechezy, szkoły wiary oraz szkoły Maryi opisywanej w Piśmie Świętym i przez Tradycję. Następnie postaram się w miarę syntetycznie ukazać właściwe ujęcie mariologii w kontekście całej teologii. Podsumowanie stanowić będzie ukazanie tajemnicy Maryi jako treści katechezy oraz sformułowanie postulatów odnoszących się do katechezy maryjnej. Zwłaszcza w tej ostatniej części postaram się odnieść do propozycji zaczerpniętych 
$\mathrm{z}$ absolutnie podstawowej dla polskiej katechezy maryjnej monografii Mariana Zająca. ${ }^{1}$ Mam nadzieję, że uda mi się przynajmniej częściowo pokazać, jak bardzo ta pionierska praca, mimo tytułu historycznego, realizuje cel predykatywny teologii.

\section{Katecheza szkołą wiary i szkołą Maryi}

Wedle określenia papieża Jana Pawła II, „katecheza jest wychowaniem w wierze dzieci, młodzieży i dorosłych, a obejmuje przede wszystkim nauczanie doktryny chrześcijańskiej przekazywane na ogół w sposób systematyczny i całościowy, dla wprowadzenia wierzących w pełnię życia chrześcijańskiego". ${ }^{2}$ Określenie to, nie będące ścisłą definicją, wskazuje przede wszystkim na adresatów i funkcje katechezy. Katecheza jest mianowicie kierowana do ludzi wierzących, niezależnie od wieku. Podstawowa jest katecheza dorosłych, bowiem wpływa na katechezę rodzinną. ${ }^{3}$ Jednak katecheza stanowi proces odnoszący się do całego życia chrześcijanina. To bardzo ważna uwaga, bowiem przywołuje przez analogię wiarę, która może rozwijać się, ale też niekiedy karleć w życiu człowieka wierzącego. Żeby zatem chrześcijanin pozostał w relacji wiary i zaufania wobec Boga, potrzebne, wręcz konieczne, jest podtrzymywanie tej relacji w rozmaity sposób, w tym przez katechezę. Z kolei funkcje katechezy, wychowanie, nauczanie i wtajemniczenie, wskazują na pewien proces formacji, który może uczynić z katechezy szkołę wiary.

Pojęcie katechezy jako szkoły wiary jest obecne w dokumentach katechetycznych. Między innymi Dyrektorium ogólne o katechizacji wśród niedostatków, z jakimi borykała się katecheza posoborowa, wymienia brak przeniknięcia w pełni do świadomości katechetów tej

M. Z a j ą c, Katecheza maryjna w Polsce w latach 1905-2005, Lublin 2006.

2 J a n P aw eł II, Adhortacja apostolska Catechesi tradendae, Watykan 1979, nr 18 (dalej: CT). Powtórzenie tej definicji znajdujemy w Katechizmie Kościoła Katolickiego, Pallottinum, Poznań 1992, nr 5.

3 Szerszą analizę określenia katechezy zob. P. To m a s i k, Katechetyka fundamentalna, w: J. S t a la (red.), Historia katechezy i katechetyka fundamentalna, Tarnów 2010, s. 200n. 
właśnie koncepcji. ${ }^{4} \mathrm{~W}$ polskiej literaturze katechetycznej koncepcję katechezy i lekcji religii jako szkoły wiary podjął Jan Szpet. Związał on ją z podkreśleniem kerygmatycznego wymiaru katechezy. Chodzi bowiem o to, że ,katecheza nie może być zbiorem prawd o Bogu, człowieku, świecie, sumą skrótów traktatów teologicznych, lecz musi zagłębiać się w treść wiary, budzić ją, rozwijać i doprowadzać do dojrzałości chrześcijańskiej. Ma pomagać dostrzegać osobę Boga, który się objawia, daje się poznać w osobie i dziele Jezusa Chrystusa, gdyż pragnie być bliski każdemu człowiekowi". ${ }^{5}$ Można postawić pytanie, czy ta zasada może być stosowana w odniesieniu do szkolnego nauczania religii. Oczywiście, bowiem zadaniem lekcji religii jest nie tylko wypełnianie funkcji nauczania, ale także wychowania oraz, choć w formie okrojonej, wtajemniczenia. Ponadto w polskiej koncepcji tych lekcji funkcje te są uzupełniane o ewangelizację, oczywiście w ramach możliwości, jakie daje szkoła publiczna. Naturalne jest zatem postulowane przez koncepcję szkoły wiary zagłębianie się w treść wiary, budzenie jej, rozwijanie i doprowadzanie do dojrzałości chrześcijańskiej. ${ }^{6}$

Warto też wyciągnąć wnioski ze stwierdzenia, że koncepcja katechezy jako szkoły wiary jest warunkowana przez relację między kerygmatem i katechezą. We współczesnym rozumieniu kerygmat oznacza „zarówno głoszenie Królestwa Bożego oraz jego zbawczych skutków, jak i samą treść przepowiadania". ${ }^{7}$ W tym kontekście można

4 Kongrega cja d s. D u chowi eń s twa, Dyrektorium ogólne o katechizacji, Pallottinum, Poznań 2002, nr 30.

5 J. S z p e t, D. J a c k o w i a k, Lekcja religii szkoła wiary, Poznań 1996, s. 12.

6 Szerzej na ten temat zob. P. To m a s i k, Ewangelizacja - istotny wymiar wyznaniowej lekcji religii w polskiej szkole, w: A. O ff m a ń s k i (red.), Polska katecheza wobec pluralizmu jednoczacej się Europy, Szczecin 2004, s. 224nn.; A. O f f $\mathrm{m}$ a ń s k i, Koncepcja katechezy o charakterze ewangelizacyjnym wedtug zasad katechumenatu, Szczecin 2010, s. 97nn.; R. C z e k a 1 s k i, Nowe formy ewangelizacji w środowisku szkolnym, w: W. P r z y g o d a, E. R o b e k (red.), Ewangelizacja odpowiedzia kościoła w Polsce na wyzwania współczesności, Sandomierz 2011, s. 167nn.

7 J. S z y m i k, Teologia. Rozmowa o Bogu i człowieku, Lublin 2008, s. 216. 
mówić o kerygmacie ewangelizacyjnym, który „ma doprowadzić słuchacza do osoby Chrystusa, do obudzenia w nim wiary wobec tego, co On objawia o Bogu Ojcu, i pobudzić do zawierzenia $\mathrm{Mu}$ całego swojego życia". ${ }^{8}$ Należy przy tym podkreślić, że „charakter kerygmatyczny ma głoszenie Ewangelii przez Kościół w ciągu całej jego historii. (...) Współcześnie podkreśla się w Kościele katolickim, by całe nauczanie wiary, także w stosunku do już wierzących, miało charakter kerygmatyczny. Nie ma być ono tylko nauczaniem w sensie zapoznawania z treścią wiary, lecz proklamacją zbawienia Chrystusa jako rzeczywistości zawsze obecnej, stającej przed każdym człowiekiem, domagającej się odpowiedzi”. ${ }^{9}$ Konieczność głoszenia kerygmatu podkreślają dokumenty ostatnich pontyfikatów.

W adhortacji Evangelii nuntiandi papież Paweł VI wiązał kerygmat z pierwszym przepowiadaniem Ewangelii, czyli z ewangelizacją w znaczeniu ścisłym. Zauważał mianowicie, że „,wieszczenie - kerygmat, kazanie lub katecheza - zajmuje ważne miejsce w ewangelizacji. Ale dodawał: Przepowiadanie osiąga swą pełną moc i znaczenie tylko wtedy, kiedy jest słuchane, przyjęte, przyswojone i kiedy w tym, kto je przyjmuje, wznieca przylgnięcie całą duszą. Ktoś mianowicie przyjmuje prawdy, które Bóg miłosierny objawił. Ale o wiele bardziej uznaje program życia - życia już odmienionego - jaki one proponują. Mówiąc krótko, ktoś przystaje do Królestwa, tzn. do «nowego świata», do nowego porządku rzeczy, do nowej drogi istnienia, do nowej zasady życia i to życia we wspólnocie, ustanowionego przez Ewangelię". ${ }^{10} \mathrm{Z}$ tych stwierdzeń jasno wynika, że nie wystarczy samo przepowiadanie kerygmatu, domaga się on potwierdzenia życiem i świadectwa życia odmienionego.

8 A. Offmań s k i Koncepcja katechezy o charakterze ewangelizacyjnym wedtug zasad katechumenatu, s. 26.

9 J. K u d a s i e w i c z, A. Z u b e r b i e r, Kerygmat, w: A. Z u b e r b i e r (red.), Stownik teologiczny, Katowice 1998, s. 238.

10 P aw e 1 VI, Adhortacja apostolska Evangelii nuntiandi, Watykan 1975, nr 22n. 
Jan Paweł II w adhortacji Catechesi tradendae, omawiając elementy przepowiadania kościelnego, mającego związek z katechezą, wymieniał ,pierwsze głoszenie Ewangelii, czyli misyjne przepowiadanie przez kerygmat dla wzbudzenia wiary; działalność apologetyczną, czyli poszukiwanie argumentów skłaniających do uwierzenia; praktykę życia chrześcijańskiego; sprawowanie sakramentów; pełne uczestnictwo we wspólnocie kościelnej i świadectwo życia apostolskiego i misyjnego". ${ }^{11}$ Kerygmat jako element pierwszego głoszenia jest ukazany w relacji do katechezy systematycznej, gdy Jan Paweł II pisze, że „nauczanie musi być wystarczająco pełne, to znaczy takie, aby nie poprzestawało na pierwszej zapowiedzi tajemnicy chrześcijańskiej, którą przekazuje kerygmat". ${ }^{12}$ Relacja kerygmatu i katechezy jest opisana w dokumencie następująco: „Kerygmat ewangeliczny, który pierwszą swą zapowiedzią, pełną zapału i żaru, tak kiedyś wstrząsnął człowiekiem i poruszył go, że oddał się on przez wiarę Jezusowi Chrystusowi, stopniowo dzięki katechezie, coraz głębiej jest pojmowany, poszerzany o wnioski, które z niego wypływają, wyjaśniany wykładem wymagającym także rozumowania $\mathrm{i} w$ ten sposób doprowadza do praktyki życia chrześcijańskiego w Kościele i w świecie. Nie jest to mniej ewangeliczne niż sam kerygmat, niezależnie od twierdzenia tych, którzy uważają, że w ten sposób katecheza z konieczności staje się przeracjonalizowana, wysusza, a w końcu gasi to, co w samym kerygmacie jest żywe, spontaniczne i płomienne. Bowiem to te prawdy, które w katechezie są pogłębiane, poruszyły kiedyś serce człowieka, gdy je po raz pierwszy usłyszał. Nie bledną one ani nie stają się bardziej płytkie przez lepsze ich poznawanie w katechezie, lecz przeciwnie, bardziej pobudzają i mają większe znaczenie dla życia". ${ }^{13}$ Wyraźnie widać, że papież Jan Paweł II opowiedział się za oddzieleniem etapu kerygmatu od etapu katechezy, ale jednocześnie wskazał na fakt, że prawda zawarta w kerygmacie jest wciąż obecna w katechezie, która jest pogłębionym przekazem.

\footnotetext{
CT, nr 18.

2 Tamże, nr 21.

13 Tamże, nr 25.
} 
Kontynuując tę myśl poprzedników, papież Franciszek nadał nowy impuls traktowaniu kerygmatu w przepowiadaniu, w tym w katechezie. Stwierdził mianowicie, że „w katechezie rolę fundamentalną odgrywa pierwsze głoszenie lub kerygmat, który powinien zajmować centralne miejsce w działalności ewangelizacyjnej i w każdej próbie odnowy Kościoła”. I dodał: „Gdy mówimy, że to orędzie jest pierwsze, nie oznacza to, że jest na początku, a potem się o nim zapomina albo zastępuje się je innymi treściami, które je przewyższają. Jest pierwsze w sensie jakościowym, ponieważ jest głównym orędziem, tym, do którego trzeba stale powracać”. ${ }^{14}$ Podkreślenie ważności kerygmatu przez papieża Franciszka polega na stwierdzeniu wprost, że prawidłowa formacja nie oznacza zaniechania kerygmatu, bowiem ,nie ma nic bardziej solidnego, bardziej głębokiego, bardziej pewnego, bardziej treściwego i bardziej mądrego od przepowiadania początkowego. Cała formacja chrześcijańska jest przede wszystkim pogłębieniem kerygmatu". ${ }^{15}$

$\mathrm{Na}$ tle tak ujętej koncepcji katechezy jako szkoły wiary warto wskazać szczególny przykład takiej szkoły, jaki zapisany jest na kartach Nowego Testamentu, a który można by nazwać szkołą Maryi. Leo Scheffczyk, analizując materiał biblijny, ukazuje postać Maryi jako Matki Zbawiciela, Dziewicy i Służebnicy Pańskiej, Świadka wiary, Matki Boleści, Początku Nowego Przymierza, Symbolu doskonałości i spełnienia. ${ }^{16}$ Szkoła wiary to przejście od wielkiej zapowiedzi zapisanej w Starym Testamencie, obecnej w przeczuciu Ludu Bożego i jego oczekiwaniu, przez konkret wypełnienia proroctwa, trud przyjęcia jego brzemienia we własnym życiu, do otwarcia się na przyszłość i wieczność, nową drogę człowieka i nową obietnicę Boga. Takie ujęcie świadectw biblijnych stanowi podstawę do ukazania miejsca Maryi w wierze Kościoła. Świadectwa te pouczają o drodze,

14 F r a n c i s ze k, Adhortacja apostolska Evangelii gaudium, Watykan 2013, nr 164 (dalej: EG).

15 Tamże, nr 165.

16 L. S c h e ff c z y k, Maryja-Matka i Towarzyszka Chrystusa, Kraków 2004, s. $11 n n$. 
którą Maryja przeszła najpierw sama z Bożą pomocą i w pełnym posłuszeństwie Służebnicy Pańskiej.

Gerhard Ludwig Müller z zarysu nowotestamentowego obrazu Maryi wydobywa cechy szkoły Maryi. Szkoła ta ma ścisłe nastawienie eschatologiczne. Maryja uczy wierzących o doczesności na tyle, na ile doczesność znajdzie swe wypełnienie w przyjściu Syna Bożego, Zbawiciela świata. Maryja jest „prawzorem stosunków człowieka z Bogiem, realizującego się w korelacji słowa i wiary (miłości)”. Maryja, jako Matka Pana, przyjęła Bożą „łaskę jako swoje zadanie i w swej relacji do Jezusa oraz pochodzącej od Niego zbawczej wspólnoty Kościoła aktywnie przekłada ją na wiarę, nadzieje i miłość". ${ }^{17}$

Bruno Forte materiał biblijny odnoszący się do Maryi segreguje na trzy kategorie, będące etapami rozwijania się objawienia biblijnego dotyczącego Matki Pana. Pierwszy etap to powściągliwe informacje znajdujące się u św. Pawła i u św. Marka; następny to pogłębienie paschalne u św. Mateusza i św. Łukasza; ostatni to przełożenie problematyki maryjnej na sytuację Kościoła męczenników i pielgrzymów, co dokonuje się w pismach Janowych. ${ }^{18}$ Podział ten związany jest nie tyle z rzeczywistym rozwojem objawienia, ile z czasem redakcji poszczególnych ksiąg Nowego Testamentu. Warto zauważyć, że poza wzmiankami historycznymi lub epizodami, które należy umieścić w szerszym kontekście, pojawiają się już od samego początku syntezy, które odwołują się do Misterium Paschalnego, choćby tekst z Ga 4, 4-5, gdzie mowa jest o ,pełni czasu”, a jednocześnie o przybranym synostwie i wolności dzieci Bożych. Autor ten podkreśla, że ta paschalna synteza, w oczywisty sposób odpowiadająca na sytuację Kościoła męczenników i pielgrzymów, jest jednocześnie pierwszą wzmianką o Maryi. ${ }^{19} \mathrm{~W}$ tej biblijnej szkole problematyka maryjna

17 G.L. Mü 11 e r, Dogmatyka katolicka, Kraków 2015, s. 509.

18 B. Fo r t e, Maryja - Ikona Tajemnicy. Zarys mariologii symboliczno-narracyjnej, Warszawa 1999, s. 50nn.

19 Por. tamże, s. 50. 
jest ukazana jako dojrzały owoc medytacji Bożego planu zbawienia świata i człowieka.

Kolejnym autorem, w którego twórczości można zauważyć elementy szkoły Maryi, jest Fulton J. Sheen. Materiał biblijny jest u tego autora ułożony wedle problemów zawartych w I części jego podstawowej książki mariologicznej, zatytułowanej Niewiasta umiłowana przez świat. Sceny ewangeliczne z problemami łączą się następująco: Miłość zaczyna się od marzenia (proroctwa), Gdy miłość $i$ wolność byly tym samym (Zwiastowanie), Pieśń kobiety (Nawiedzenie), Dziewicza Matka (Narodzenie Pańskie), Najszczęśliwsze małżeństwo świata (Św. Rodzina), Postuszeństwo i miłość (Znalezienie Jezusa), Wesele w Kanie, Miłość i smutek (Golgota), Wniebowzięcie $i$ świat współczesny. ${ }^{20}$ Opracowanie Fultona J. Sheena nie jest książką naukową w sensie ścisłym, autor bowiem nie chce przedstawiać wyników badań naukowych, raczej popularyzuje temat w postaci pogadanek, mających jednak bardzo mocną podstawę biblijną i teologiczną i odnoszących się do literatury i kontekstu, w jakim żyją adresaci. Można zatem powiedzieć, że prezentuje on propozycję katechezy jednocześnie biblijnej i egzystencjalnej. Na tym etapie pojawia się propozycja katechetyczna, bardzo interesująca i stanowiąca punkt odniesienia dla tego, jak powinno się mówić o Maryi w katechezie.

Podsumowując zagadnienie biblijnej szkoły Maryi, warto zwrócić uwagę na syntezę, jakiej dokonał w encyklice Redemptoris Mater papież Jan Paweł II. Analizuje on trzy aspekty biblijnej nauki o Maryi, które wyznaczają cytaty ewangeliczne: „Łaski pełna”, „Błogosławiona, która uwierzyła”, „Oto Matka twoja”. I stwierdza, że „wychodzenie [Maryi] naprzeciw potrzebom człowieka oznacza równocześnie wprowadzenie ich w zasięg mesjańskiej misji i zbawczej mocy Chrystusa. Jest to więc pośrednictwo: Maryja staje pomiędzy swym Synem a ludźmi w sytuacji ich braków, niedostatków i cierpień. Staje «pomiędzy», czyli pośredniczy, nie jako obca, lecz

20 F.J. S h e e n, Maryja, pierwsza miłość świata, Kraków 2018, s. 29nn. 
ze stanowiska Matki, świadoma, że jako Matka może - lub nawet więcej: «ma prawo» - powiedzieć Synowi o potrzebach ludzi”. ${ }^{21}$

\section{Prawidłowe ujęcie mariologii}

Nie wolno zapomnieć, że tematy mariologiczne nie mogą w katechezie stanowić wyizolowanego obszaru treściowego, co wynika również z faktu, że mariologia nie stanowi wyizolowanej subdyscypliny teologicznej. Dobra teologia generuje dobrą mariologię, błędy teologiczne powodują, że mariologia jest albo przerysowana albo zredukowana, np. do kwestii pobożnościowych, albo też zostaje całkowicie usunięta $\mathrm{z}$ teologii.

Problemem jest bowiem mniejsze zainteresowanie problemami mariologicznymi, zwłaszcza odnoszącymi się do pobożności maryjnej, w niektórych regionach, szczególnie w krajach języka niemieckiego. Mówił o tym w 1982 r. Joseph Ratzinger, nota bene, w kontekście kanonizacji o. Maksymiliana Kolbego: „Traktowaliśmy duszę i serce w naszej wierze, z lęku przed zarzutem fałszywego sentymentalizmu - zbyt sceptycznie, wręcz pogardliwie, aż w końcu całkowicie je wyrugowaliśmy z wiary. Ale wiara, której brakuje pożywki dla serca, która jest tylko rozumowa, w końcu usycha. Tam, gdzie zaakceptujemy maryjność w chrystologii, gdzie urzeczywistnimy od wewnątrz, że Jezus mówił do tylko jednej osoby «Matko», tam zostanie ujęta dogłębnie istota naszego bytu; wtedy urzeczywistnia się wymiar serca w wierze i w ten sposób wiara może przeniknąć do głębi i ożywiać całe nasze życie". ${ }^{22}$

Problem tego milczenia o mariologii był związany z dążeniami ekumenicznymi, chyba nie do końca zrozumianymi. Joseph Ratzinger podkreślał, że źródłem owego zdystansowania były ,pytania naszych

${ }^{21}$ J a n P a w e 1 II, Encyklika Redemptoris Mater, Watykan 1987, nr 20 (dalej: RMa).

22 J. R a t z i n g e r, Aggiornamento. Homilia wygłoszona w Rzymie 12 X 1992, w: t e n ż e, Opera omnia, t. 7: O nauczaniu II Soboru Watykańskiego. Formułowanie - przekaz - interpretacja, Lublin 2016, s. 963. 
braci ewangelików, czy [maryjność] nie ogranicza czci należnej Chrystusowi, czy [maryjna] forma pobożności i wiary nie zatrzymuje się przy stworzeniu, zamiast iść do samego Pana. I dodaje, że ruchy reformujące naszych czasów, w których rzeczywiście rozwija się nowa żywa wiara i nowy zachwyt Chrystusem, są nacechowane głęboką miłością do Matki Pana". ${ }^{23}$ Tutaj dotykamy kwestii zasadniczej dla katechezy maryjnej: winna ona głosić chrystologię prawidłową, czyli wskazującą na Pana jako na Boga i człowieka, jednocześnie winna wskazywać na antropologię katolicką, w której w sposób harmonijny uwzględnia się zarówno aspekt pierwotnego impulsu łaski Bożej, jak i odpowiedzi człowieka, który jest wolny, a nie spętany predestynacją. Ekumenizm nie jest wart tego, by składać mu ofiarę z prawd wiary. Gdy taką ofiarę się składa, ekumenizm staje się zaprzeczeniem siebie, staje się światowym uzgadnianiem stanowisk, przyjmującym nierzadko postać zgniłego kompromisu. Tymczasem celem dialogu ekumenicznego jest pogłębienie wiary, jej prawdy, prawdziwości jej przeżywania. Tylko na gruncie prawdy można budować miłość wolną od udawania. Zatem prawda o Jezusie Chrystusie, jak i prawda o człowieku domagają się, by mówić o Maryi, Matce Boga, a jednocześnie Niepokalanej Dziewicy, w której wstawiennictwo i świętość Kościół wierzy.

Przy okazji tematyki antropologicznej warto jeszcze zasygnalizować zagadnienie, jakie pojawia się w teologii ostatnich czasów, mianowicie feministyczną interpretację mariologii. Kamieniem obrazy jest w nurcie radykalnym nazywanie Maryi pokorną Służebnicą, co miałoby się jakoby przyczynić się do deprecjonowania kobiety. ${ }^{24}$ Nurt feministyczny nie chce pogodzić się ze związaniem ideału Maryi z Jej macierzyństwem, co wyraźnie sugeruje papież Jan Paweł II w liście apostolskim Mulieris dignitatem ${ }^{25}$. Elżbieta Adamiak, polska przedstawicielka tego sposobu rozumowania, stwierdza, że

\footnotetext{
Tamże, s. 962.

G.L. M ü 11 e r, Dogmatyka katolicka, s. 500.

25 Por. J a n P awe ł II, List apostolski Mulieris dignitatem, Watykan 1988,
} nr 19. 
„części współczesnych kobiet trudno odnaleźć się w takim wzorze kobiecości”, bowiem w postać Maryi Kościół wpisał określony wzór kobiecości. ${ }^{26}$ Rozumowanie to jest nie w pełni logiczne, bowiem Maryja jest czczona w Kościele z powodu Boskiego macierzyństwa, powiązanie mariologii z chrystologią stanowi podstawę zarówno dla teologicznej refleksji nad postacią Maryi, jak i dla katechezy o Maryi. Problematyczne jest w tym sposobie rozumowania, zgodne zresztą z dzisiejszą światową mentalnością, radykalnie odmienną od ducha Ewangelii, roszczeniowe stawianie problemów. ${ }^{27}$ Tymczasem miejsce kobiety w Kościele winno być darem Boga, a nie wynikiem gry interesów, dokładnie jak miejsce mężczyzny. Taka jest optyka Ewangelii i żadna nauka światowa, nawet posługująca się językiem teologii, nie może tego zmienić.

Z chrystologicznego źródła mariologii wypływa jeszcze jedna nauka. Chodzi mianowicie o związek Maryi z Kościołem. W trakcie II Soboru Watykańskiego zdecydowano się, by nie wydawać odrębnego dokumentu odnoszącego się do Matki Pana, ale kwestie mariologiczne umieścić w konstytucji dogmatycznej o Kościele $L u$ men gentium jako odrębny rozdział. Była to decyzja doniosła, wywołująca zrazu niemałe kontrowersje, podjęta przy widocznym braku jednomyślności. Trzeba mocno podkreślić, że większości zwolenników włączenia tematyki maryjnej w zagadnienia eklezjologiczne nie chodziło o umniejszenie czci Maryi. Można dywagować o stylu, jaki towarzyszył podjęciu tych decyzji, ${ }^{28}$ jednak trzeba podkreślić ortodoksyjność tego aktu. Co więcej, warto zauważyć, że to włączenie przyniosło bardzo pozytywne - przynajmniej z punktu widzenia

${ }^{26}$ E. A d a m i a k, Traktato Maryi, w: E. Ad a m i a k, A. C z a ja, J. M aj e w s k i (red.), Dogmatyka, t. 2, Warszawa 2006, s. 175n.

27 Por. J. R a t z i n g e r, Aggiornamento, s. 964.

28 Szerzej o tej zażartej dyskusji zob. J.W. O 'M a 11 e y, Co się zdarzyło podczas Soboru Watykańskiego II, Kraków 2011, s. 235; R. d e M a t te i, Sobór Watykański II. Historia dotąd nieopowiedziana, Ząbki 2012, s. 237nn.; J. R a t z i n g e r, Sobór w drodze. Spojrzenie wstecz na II sesję II Soboru Watykańskiego, w: t e n ż e, Opera omnia, t. 7: O nauczaniu II Soboru Watykańskiego, s. 338n; R.M. W i 1 t g e n, Ren wpada do Tybru. Historia Soboru Watykańskiego II, Poznań 2001, s. 112nn. 
katechetycznego - owoce. Maryja mianowicie jest przedstawiana jako pierwsza wierząca, zaś podkreślenie w tekście konstytucji Lumen gentium zagadnienia świętości pozwala także ukazać Maryję jako pierwszą ze świętych, uzasadnić pobożność maryjną, przekraczającą pobożność związaną z kultem świętych Pańskich, wreszcie uzasadnić pośrednictwo Maryi, które ma źródło w jedynym pośrednictwie Jezusa Chrystusa. ${ }^{29} \mathrm{~W}$ ten sposób pobożność maryjna zyskała mocne podstawy teologiczne, a można powiedzieć jeszcze dobitniej: mocne podstawy w całości wiary Kościoła. ${ }^{30}$ Ponadto maryjność niesie ze sobą silny ładunek egzystencjalny: jest Ona pokorną służebnicą Pańską, która Bóg uczynił wielką, uosabia Kościół ubogich i Kościół, który wyrasta z korzenia Izraela, pod swoim sercem niesie zaś nadzieję świata. ${ }^{31}$ Warte zauważenia jest tu wychylenie ekumeniczne: względy ekumeniczne były bowiem powodem kryzysu wokół problematyki mariologicznej na Soborze, zarzucano grupie tzw. minimalistów realizacje celów koniunkturalnych, co więcej, nie da się wykluczyć, że takie podejście powodowało niektórymi z nich, jednak skutek okazał się prawdziwą felix culpa: dał podstawę, by o Maryi rozmawiać spokojnie także z denominacjami wyrosłymi z reformacji.

\section{Tajemnica Maryi jako treść katechezy}

Katechetyczne ujęcie mariologii należy wiązać szczególnie z kontekstem treściowym. Treści katechetyczne odnoszące się do Maryi są wyrażone zarówno przez teksty biblijne, jak i dogmaty maryjne stanowiące syntezę Biblii i Tradycji.

Maryja jest Matką Boga. Tytuł ten jest związany w sposób oczywisty następującymi faktami: tym, że jest Matką Jezusa jako jednej

29 J. R a t z i nge r, Wprowadzenie do Konstytucji dogmatycznej o Kościele „Lumen gentium”, w: te n ż e, Opera omnia, t. 7: O nauczaniu II Soboru Watykańskiego, s. 580nn.

30 F. C o u r t h, Mariologia. Maryja, Matka Chrystusa, w: W. B e i n e r t (red.), Podręcznik teologii dogmatycznej, Kraków 1999, s. 75nn.

31 J. R a t z i n ge r, Sobór w drodze. Spojrzenie wstecz na II sesję II Soboru Watykańskiego, s. 339. 
Osoby, choć mającej dwie natury, oraz że Jezus jest Bogiem. Warto podkreślić, że tytuł ten nie ma żadnych odniesień pogańskich, co sugerują niektórzy liberalni teologowie, bowiem powstał on $\mathrm{z}$ wewnętrznych powodów teologicznych. ${ }^{32}$ Jak zauważa Gerhard L. Müller, w naturze Boskiej „Logos pochodzi tylko od Boga, zaś człowieczeństwo przyjmuje z Maryi w czasie i historii. macierzyństwo nie polega jednak na samej naturalnej relacji. Podmiotem rodzenia i podmiotem bycia rodzonym jest zawsze osoba, w związku z czym między matka i dzieckiem w poczęciu i narodzinach powstaje relacja osobowa". ${ }^{33}$ Tę prawdę Kościół rozstrzygnął w kontekście sporów nestoriańskich. ${ }^{34}$ Warto też zwrócić uwagę na szerszą interpretację tytułu „Matka”, jakiej dokonuje Czesław S. Bartnik, wyodrębniając w ramach tego określenia następujące tytuły: „Matka Jezusa”, „Bogurodzica”, „Pośredniczka w Chrystusie”, „Matka Kościoła”, „Szafarka łask wszelkich”, „Matka rodziny”, „Matka narodu”. ${ }^{35}$

Drugi dogmat maryjny głosi, że Maryja była i jest Dziewicą. Tytuł ten ma mocne podstawy biblijne. Dogmat ten był niekwestionowany w starożytności z nielicznymi wyjątkami niektórych gnostyków, w nowożytności także długo po reformacji. Dopiero teologia liberalna, przeinaczająca chrystologię, jednocześnie podała w wątpliwość ten dogmat. ${ }^{36}$ Należy podkreślić za Gerhardem L. Müllerem, że podstawę tego dogmatu ,stanowi nie wroga ciału asceza, lecz idea całkowitego poświęcenia się Maryi sprawie królestwa Bożego. Widać tutaj, że chrześcijańska forma dziewiczego życia nie jest sprzeczna z chrześcijańską koncepcją małżeństwa i nie jest produktem gnostycko-manichejskiej ascezy wrogiej ciału". ${ }^{37}$ Takie postawienie problemu ma duże znaczenie katechetyczne.

\footnotetext{
32 L. S c h e ffe z y k, Maryja - Matka i Towarzyszka Chrystusa, s. 99nn.

33 G.L. Mü 11 e r, Dogmatyka katolicka, s. 518.

34 F. C o u r t h, Mariologia. Maryja, Matka Chrystusa, s. 103nn.

35 Cz. S. B a r t n i k, Dogmatyka katolicka, t. 2, Kraków 2003, s. 407nn.

${ }^{36}$ L. S c he ff c z y k, Maryja - Matka i Towarzyszka Chrystusa, s. 116n.

37 G.L. Mü 11 e r, Dogmatyka katolicka, s. 517.
} 
Kolejny dogmat maryjny dotyczy Niepokalanego Poczęcia. Został on ogłoszony w XIX w., jednak, jak całość Tradycji, ma on charakter zakorzeniony w starożytności. Dogmat ten, wcześniej strzeżony w liturgii i pielęgnowany przez pobożność wiernych, ma, podobnie jak poprzednie, istotne odniesienie chrystologiczne, ale wnosi wiele do katolickiej antropologii. Otóż ukazuje on Maryję jako Wybraną i Obdarzoną łaską. ${ }^{38}$ Ponieważ to ujęcie dotyczy Matki Pana, zatem to wybranie i napełnienie łaską ma charakter całkowity, absolutny, dlatego też nie dotyka Maryi skaza grzechu pierworodnego. Istotnym skutkiem tego dogmatu jest poszerzenie refleksji mariologicznej w kierunku pneumatologii: Maryja jest Świątynią Ducha Świętego, znowu w sposób pełny, jak tylko możliwe jest to w odniesieniu do stworzeń. ${ }^{39} \mathrm{~W}$ przekazie katechetycznym należałoby wskazywać, że dogmat ten łączy się z wolnością, która „nie jest ograniczona przez nadprzyrodzone przeznaczenie wszystkich do zbawienia, lecz otrzymuje motywację potrzebną do jej aktualizowania". ${ }^{40}$

Ostatni z ogłoszonych dotychczas dogmatów maryjnych odnosi się do wniebowzięcia Matki Pana. Podstawą tej zdefiniowanej przez Kościół prawdy jest związek, jaki łączył ciało Jezusa z ciałem Maryi. Rozkład ciała jest skutkiem grzechu pierworodnego, tymczasem Maryja była wolna od rzeczywistości grzechu. ${ }^{41}$ Macierzyństwo Maryi wobec Kościoła wiąże się z faktem, że pozostaje Ona Matką Głowy Mistycznego Ciała. ${ }^{42}$ Jest apokaliptyczną Niewiastą, która $\mathrm{u}$ boku swego Syna walczy z nieprzyjacielem Boga i pokonuje go. ${ }^{43}$

Do czterech maryjnych dogmatów warto w przekazie katechetycznym dodać jeszcze trzy aspekty mówienia o Maryi w czasach współczesnych. Aspekty te są zarówno owocem rozwoju myśli

38 F. C o u r t h, Mariologia. Maryja, Matka Chrystusa, s. 155nn.

39 L. S c h eff c z y k, Maryja - Matka i Towarzyszka Chrystusa, s. 143nn.

40 G.L. Mülle r, Dogmatyka katolicka, s. 522.

${ }^{41}$ L. S c heffc z y k, Maryja - Matka i Towarzyszka Chrystusa, s. 162.

42 Cz. S. B a r t n i k, Dogmatyka katolicka, t. 2, s. 481.

43 G.M. B a r t o s i k, Z Niej narodzit się Jezus. Szkice z mariologii biblijnej, Niepokalanów 2013, s. 104. 
mariologicznej, jak też stanowią odpowiedź na wyzwania, przed którymi staje współczesna ewangelizacja.

Pierwszy z tych aspektów dotyczy Maryi jako pierwszej Wierzącej. Kwestię tę podkreślił papież Jan Paweł II w encyklice Redemptoris Mater, zwracając uwagę, że Maryja „stała się rzeczywiście obecna w tajemnicy Chrystusa przez to, że uwierzyła". ${ }^{44}$ Dlatego też wiara Maryi jest rozpatrywana w tym dokumencie w odniesieniu do wielu świadków wiary. Zwraca się tam uwagę przede wszystkim na fakt posłuszeństwa wierze. ${ }^{45}$ Komentując ten fragment encykliki, Joseph Ratzinger zauważa, że ,podobnie jak u Abrahama, tak i u [Maryi] wiara jest zaufaniem Bogu i posłuszeństwem wobec Niego okazywanym na ciemnej drodze. Jest zapomnieniem o sobie, powierzeniem się i oddaniem prawdzie i Bogu. W ten sposób wiara jest $\mathrm{w}$ półcieniu niezbadanych dróg Bożych upodabnianiem się do Niego". ${ }^{46} \mathrm{~W}$ encyklice Lumen fidei czytamy z kolei, że ,gdy nadeszła pełnia czasu, Słowo Boże zwróciło się do Maryi, a Ona przyjęła Je całym swoim jestestwem, w swoim sercu. (...) wiara Matki Jezusa była owocna, a kiedy nasze życie duchowe przynosi owoce, napełnia nas radość, będąca najbardziej wyraźnym znakiem wielkości wiary". ${ }^{47}$ Istotą obrazu Maryi jako pierwszej Wierzącej jest zatem wezwanie do wiary jako radosnego przylgnięcia do Boga i Jego woli, a także posłuszeństwo wiary, co stanowi w dzisiejszych czasach, głoszących indywidualizm i zacieśniających horyzont zbawienia do doczesności, nie lada problem.

Drugi współczesny aspekt mariologii odnosi się do tytułu Matki Kościoła. Tytuł ten mocno wiąże się z soborowymi dyskusjami mariologicznymi. Umiejscowienie tematyki maryjnej w konstytucji dogmatycznej o Kościele w sposób naturalny czyniło zrozumiałym ten tytuł. Jednakże, mimo wielkiego zaangażowania papieża Pawła VI,

${ }_{44} \mathrm{RMa}, \mathrm{nr} 12$.

45 Tamże, nr 14.

46 J. R a t z i n ge r, Znak Niewiasty, w: J. R a t z inge r, H.U. v o n B a l t h a s a r, Maryja w tajemnicy Kościoła, Kraków 2007, s. 42.

47 Fr a n c i s z e k, Encyklika Lumen fidei, Watykan 2013, nr 58. 
by tytuł ten został uroczyście proklamowany, pojawiły się wśród ojców soborowych duże obiekcje, jakoby był to tytuł dwuznaczny, sugerujący postawienie Maryi ponad Kościołem i umiejscowieniem Matki Pana poza wspólnotą Jego uczniów. ${ }^{48}$ Interesująca jest dalsza droga oswajania nieprzekonanych z tym ważnym tytułem maryjnym. Paweł VI ogłosił Maryję Matką Kościoła nie aktem uroczystym, ale w trakcie przemówienia zamykającego III sesję II Soboru Watykańskiego. ${ }^{49}$ Tytuł został dołączony przez tego papieża do litanii loretańskiej, zaś święto Maryi Matki Kościoła, na prośbę Konferencji Episkopatu Polski, włączono do kalendarza krajowego. Dopiero jednak papież Franciszek zarządził, że wspomnienie Matki Kościoła stanie się obowiązujące w całym Kościele powszechnym. Tytuł Matki Kościoła znaczy tyle, że „nie można widzieć w Maryi «bogini» lub Odkupicielki u boku Odkupiciela. (...) Maryja ma swoje miejsce w ramach Kościoła i pośród zbawionych, gdyż stoi jako pierwsza zbawiona i wzorzec Kościoła na samym początku". ${ }^{50}$

Trzeci na nowo podejmowany i dyskutowany tytuł maryjny to tytuł Pośredniczki. Zdaniem Josepha Ratzingera, tytuł ten ma charakter liturgiczny, używany jest w modlitwach, nie ma natomiast „rangi precyzyjnego terminu teologicznego. Inaczej mówiąc, tytuł ten jest formą zwracania się w obrębie relacji modlitwy, a to oznacza, że jest słowem serca, ofiarnej miłości, które to jednak - jak często słowa miłości - może stać się fałszywe, gdzie przeniesie się je na teoretyczną absolutność". ${ }^{11} \mathrm{Na}$ interesujący aspekt pośrednictwa Maryi zwraca uwagę papież Jan Paweł II w encyklice Redemptoris Mater. Chodzi mianowicie o to, że Maryja pośredniczy nie tylko modlitwom wiernych oraz spływaniu na nich łask Bożych, ale także w przekazywaniu woli Syna, czyli, po prostu, wzywa do nawróce-

48 L. S c heffc z y k, Maryja - Matka i Towarzyszka Chrystusa, s. 186; zob. także R. A m e r i o, Iota unum. Analiza zmian w Kościele katolickim w XX wieku, Komorów b.r.w., s. 119nn.

49 Zob. apologię tego przemówienia i tytułu Matki Kościoła w RMa, nr 47.

50 L. S c h effc z y k, Maryja - Matka i Towarzyszka Chrystusa, s. 182.

${ }_{51}$ J. R a t z i n ge r, Wprowadzenie do Konstytucji dogmatycznej o Kościele „Lumen gentium”, s. 581. 
nia. Odnosząc się do Ewangelii o pierwszym znaku Pana danym uczniom w Kanie Galijskiej, papież Jan Paweł II pisze tak: „Matka Chrystusa staje się wobec ludzi rzecznikiem woli Syna, ukazując te wymagania, jakie winny być spełnione, aby mogła się objawić zbawcza moc Mesjasza". ${ }^{52}$ Nie można zatem iść za skrajnymi stanowiskami, jakie wyklarowały się już w starożytności chrześcijańskiej: odrzucenia tytułów maryjnych i kultu związanego z Matką Pana albo przeciwstawnie, oddawania czci Maryi jako bogini. ${ }^{53}$ Wydaje się, że najbardziej dobitnie kwestię tę wyjaśnia Czesław S. Bartnik, gdy opowiada się zdecydowanie za ideą zawartą w schemacie nieuchwalonego dokumentu soborowego De Beata, stwierdzającego, że „Maryja jest Pośredniczką w Chrystusie, które to pośrednictwo nie jest skierowane obok Chrystusa, lecz do Chrystusa jako Boga-Człowieka, a przez Niego do Ojca i Ducha Świętego". ${ }^{44}$

Ostatni z omawianych tytułów maryjnych prowadzi do zagadnienia, które jest istotne dla katechezy w trakcie realizacji dwóch zadań katechezy, mianowicie wychowania liturgicznego i wprowadzenia do modlitwy. Odniesienie do Matki Jezusa ma swoje mocne ugruntowanie w aspekcie kultycznym i pobożnościowym, bowiem konieczne jest „ocieplenie teologii przez żywą wiarę". ${ }^{55}$ Nie chodzi tu o podejmowanie działań podobnych do pijarowego ocieplania wizerunku, raczej o zrozumienie, że teologia to nie zimne rozumowanie, że prawdy wiary winny być nie tylko przemyślane, ale też przemodlone i celebrowane.

Podstawą dla kultu i pobożności maryjnej jest tytuł, jakim Maryję obdarza archanioł Gabriel w scenie zwiastowania: Łaski pełna. Joseph Ratzinger wyjaśnia, że „być w łasce: znaczy być wierzącym. Wiara zawiera w sobie elementy stałości, pewności i oddania, ale również moment ciemności. (...) Modelu «partnerstwa», który stał się

52 RMa nr 21.

53 Szerzej na ten temat zob. G.L. M ü 11 e r, Dogmatyka katolicka, s. 526.

54 Cz. S. B a r t n i k, Dogmatyka katolicka, t. 2, s. 428.

55 J. R a t zi nge r, Wprowadzenie do Konstytucji dogmatycznej o Kościele „Lumen gentium”, s. 582. 
nam tak bliski, nie można odnosić do Boga, ponieważ nie może on wyrazić wielkości Boga i Jego ukrytego działania. Człowiek całkowicie otwarty na Boga jest zdolny zaakceptować inność Boga i tajemne zamysły Jego woli, które dla naszej woli mogą stać się przenikającym nas mieczem". ${ }^{56}$ Takie ujęcie prowadzi do widocznych wniosków katechetycznych. Wbrew logice samowystarczalności, wbrew duchowi świata, należy głosić prymat nie tylko Boga, ale tez prymat łaski, od której człowiek jest zależny, która staje się drogą zbawienia każdego z nas. Wszystko, co możemy o Maryi powiedzieć, wynika właśnie z przyjęcia łaski Bożej, z tego, że łaskę tę przyjęła w pełni. Punktem wyjścia jest Bóg dający łaskę i człowiek jako jej adresat. Następnie dokonuje się wolny akt woli człowieka przyjmującego łaskę Boga, co ma miejsce zarówno w sanktuarium sumienia, jak i w przestrzeni wspólnoty, aby ostatecznie zwyciężyła łaska. ${ }^{57}$ To jest ujęcie na wskroś katolickie, szanujące prymat Boga, a jednocześnie wolność człowieka.

Takie postawienie sprawy prowadzi do stwierdzenia, że nie ma konkurencji między chwałą Bożą a czcią oddawaną Maryi. ${ }^{58}$ Chodzi jednocześnie, by nauczanie Kościoła o Maryi prowadziło do kultu właściwego, ${ }^{59} \mathrm{którego} \mathrm{wewnętrzną} \mathrm{formę} \mathrm{stanowi} \mathrm{zawierzenie.} \mathrm{Ade-}$ kwatna jest w tym kontekście propozycja św. Ludwika Marii Grignon de Monforta, który proponuje osobiste zawierzenie jako „najbardziej intensywną formę kultu maryjnego. Wierny, poświęcając się Maryi, dokonuje, w oparciu o wiarę w trwałe i zbawienne pośrednictwo dziewiczej Matki Bożej, aktu świadomego i zdecydowanego oddania życia Maryi i spędzenia go na Jej służbie". ${ }^{60}$

56 Te n ż e, Easki pelna. Elementy pobożności maryjnej, w: J. R a t z i n ge r, H.U. vo n B a l th a s a r, Maryja w tajemnicy Kościoła, s. 60.

57 G.L. M ü 11 e r, Dogmatyka katolicka, s. 527nn.

58 L. S c heff c z y k, Maryja - Matka i Towarzyszka Chrystusa, s. 229n.

59 Szerzej na te temat zob. F. C o u r t h, Mariologia. Maryja, Matka Chrystusa, s. $193 \mathrm{nn}$.

${ }^{60}$ L. S c heffc z y k, Maryja - Matka i Towarzyszka Chrystusa, s. 284n. 


\section{Zasady katechezy maryjnej}

Wspomniana na początku niniejszego opracowania praca Mariana Zająca formułuje następujące zasady katechezy maryjnej: ${ }^{61}$

- Katecheza maryjna winna przeciwstawiać się zniekształceniu obrazu Maryi.

- Katecheza maryjna winna uaktywniać proces wpływania idei maryjnych na codzienne życie katechizowanych.

- Tematyka maryjna winna znaleźć właściwe miejsce w katechezie.

- Poza powyższymi zasadami zostały też ukazane perspektywy katechezy maryjnej w warunkach polskich, które Marian Zając sprowadza do następujących trzech punktów:62

- Należy pogłębić aktualną naukę Kościoła o Maryi.

- Winno się wprowadzić polską katechezę maryjną w przestrzeń ogólnokościelną.

- Należy powiązać liturgię i pobożność ludową z katechezą maryjną.

Zarówno zasady, jak i perspektywy katechezy maryjnej, mają charakter postulatywny, domagają się realizacji przy każdym układzie programowym. Zostały one przez autora pracy uzasadnione, nie budzą wątpliwości, a przedstawione w niniejszym opracowaniu rozważania, mam nadzieję, mogą przyczynić się do ich wprowadzenia w życie. Jest jednak pewne zagadnienie, które domaga się rozwinięcia. Chodzi mianowicie o zasadę, by tematyka maryjna znalazła w katechezie właściwe miejsce. W sposób oczywisty ta zasada jest warunkiem koniecznym realizacji pozostałych zasad i postulatów. Obecnie trwa proces formowania się nowych dokumentów programowych katechezy polskiej, co pociągnie za sobą zmianę podręczników i dość zasadnicze przebudowanie procesu katechetycznego w Polsce.

W zatwierdzonej 8 VI 2018 r. przez Konferencję Episkopatu Polski Podstawie programowej katechezy problematyka maryjna pojawia się

${ }_{61}$ M. Z a j ą c, Katecheza maryjna w Polsce w latach 1905-2005, s. 315nn.

62 Tamże, s. 355nn. 
wielokrotnie. Na poziomie przedszkolnym, mającym charakter wprowadzenia w wiarę, treści maryjne pojawiają się już na poziomie celów katechetycznych - wymagań ogólnych, w ujęciu chrystocentrycznym jako ,ukazanie Jezusa Chrystusa - Syna Bożego zrodzonego z Maryi, czyli zapoznanie z Osobą Jezusa Chrystusa, ale też ukazanie roli Maryi w dziele zbawienia". ${ }^{33}$ Wśród treści katechetycznych pojawia się hasło: „Maryja - Matka Jezusa i Matka nasza”. ${ }^{64}$

Katecheza w klasach I-IV szkoły podstawowej stanowi cykl komunijny i obejmuje inicjację w sakramenty pokuty i pojednania oraz Eucharystii. W celach katechetycznych - wymaganiach ogólnych zakłada się, w ramach wprowadzenia w tajemnice roku liturgicznego, m.in. „ukazanie obecności Chrystusa, Maryi i świętych w roku liturgicznym". ${ }^{5}$ Treści, a także związane z nimi wymagania szczegółowe i postawy, odnoszą się do kilku zadań katechezy. W ramach rozwijania poznania wiary przewiduje się treść Maryja Matka Chrystusa i naszą, co domaga się wyjaśnienia tej treści i przyjęcia Maryi za swoją Matkę i okazywania Jej szacunku. ${ }^{66} \mathrm{~W}$ ramach wychowania liturgicznego przewidziane jest wymaganie zakładające, że „uczeń ukaże związek nabożeństw ze czcią do Jezusa ukrzyżowanego, Najświętszego Serca Pana Jezusa i Maryi". ${ }^{67}$ Wychowanie do modlitwy domaga się realizacji treści: Maryja Nauczycielka modlitwy, powiązanej z licznymi wymaganiami (charakteryzuje modlitwę Maryi, omawia modlitwę Magnificat, podaje z pamięci najważniejsze maryjne modlitwy, wymienia przykładowe sytuacje, w których warto modlić się za wstawiennictwem Maryi) oraz postawami (na wzór Maryi modli się w różnych okolicznościach życia, w modlitwie stawia Panu Bogu pytania jak Maryja i jak Ona poddaje się woli Bożej, wraz z Maryją wielbi Boga, prosi Go i ufa Mu) ${ }^{68}$ Wśród minimalnego

${ }^{63}$ Konferencja Episkopatu Polski, Podstawa programowa katechezy, WAM, Kraków 2018, 0, II.

${ }_{64}$ Tamże, 0, A.3.

65 Tamże, 1, III.

${ }_{66}$ Tamże, 1, A.4; A.4.2; A.4.b.

${ }_{67}$ Tamże, 1, B.7.2.

${ }_{68}$ Tamże, 1, D.5; D.5.1-4; D.5.a-c. 
zestawu modlitw do wyuczenia na pamięć znajduje się modlitwa Zdrowaś Maryjo. ${ }^{69}$ Ponadto zaleca się zorganizowanie dla dzieci pielgrzymki do sanktuarium maryjnego, zgodnie ze zwyczajami diecezji i parafii.

W klasach V-VIII szkoły podstawowej nauczanie religii służy katechezie mistagogicznej, wprowadzającej w historię zbawienia. W ramach rozwijania poznania wiary proponuje się wśród wymagań szczegółowych wyjaśnienie czterech dogmatów maryjnych. ${ }^{70}$ W realizacji wychowania liturgicznego proponuje się wymagania polegające na wymienianiu i opisywaniu miesięcy i świąt maryjnych, ${ }^{71}$ charakteryzowanie istoty kultu Maryi oraz świętych, ${ }^{72}$ a także postawę odnoszącą się do naśladowania przykładu Maryi i świętych. ${ }^{73}$ Zadanie wychowania do modlitwy odnosi się do treści związanych z różańcem jako streszczeniem Ewangelii. W tym kontekście sformułowane są wymagania i postawy (uczeń przedstawia, na czym polega odmawianie różańca, wymienia jego części i tajemnice, uzasadnia, że modlitwa różańcowa jest rozważaniem wydarzeń z życia Jezusa i Maryi, uzasadnia związek modlitwy różańcowej z życiem chrześcijanina). ${ }^{74} \mathrm{~W}$ ramach wychowania do życia we wspólnocie, przy omawianiu treści z historii Kościoła w Polsce, pojawia się wymaganie, zgodnie z którym uczeń ukazuje rolę Maryi w historii Polski w celu zachowania wolności i tożsamości chrześcijańskiej Polski: cud nad Wisłą, akty oddania Polski Maryi i Jej Sercu w 1946 oraz 1966 r. i ich owoce. ${ }^{75}$

W szkole ponadpodstawowej nauczanie religii wiąże się z katechezą tożsamości chrześcijańskiej. Pierwsza treść odnosząca się do rozwijania poznania wiary dotyczy Maryi w Bożym zamyśle zbawienia świata i człowieka. Generuje ona wymagania (uczeń opowiada

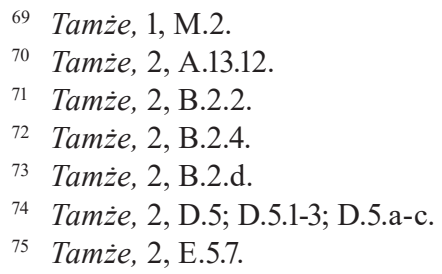


historię Maryi i wyjaśnia Jej rolę w życiu Kościoła, świata i chrześcijanina, omawia cztery dogmaty maryjne) oraz postawę, zgodnie z którą uczeń kształtuje w sobie pobożność maryjną oraz matczyną relację z Matką Bożą. ${ }^{76}$ Druga treść w ramach tego samego zadania katechezy ma szerszy charakter i dotyczy obcowania świętych, zaś element maryjny wyrażony jest przez hasło: Maryja zjednoczona ze swoim Synem; wniebowzięcie NMP. Treść ta generuje wymagania i postawy, zgodnie z którymi uczeń definiuje macierzyńską rolę Maryi wobec Kościoła i każdego wierzącego oraz wniebowzięcie Maryi, także dąży do świętości, a także kształtuje w sobie postawę miłości do Maryi i naśladuje Ją w drodze do nieba. ${ }^{77}$ Wychowanie liturgiczne przewiduje treści maryjne w ramach realizacji haseł: Maryja $w$ liturgii $i$ w pobożności ludowej; Maryja w polskiej tradycji katolickiej. Wynikają z nich konkretne wymagania (uczeń omawia sposoby obecności Maryi w pobożności ludowej i polskiej tradycji katolickiej, wymienia najważniejsze uroczystości i święta maryjne) i postawy (pielęgnuje tradycje związane z pobożnością maryjną, włącza się w obchody uroczystości i świąt ku czci Maryi, modli się do Matki Bożej, pogłębia swoją więź z Matką Bożą). ${ }^{78} \mathrm{Na}$ tym etapie kształcenia treści maryjne pojawiają się także w formacji moralnej jako hasło: Biblijne wzory postuszeństwa (Abraham, Maryja), przykłady świętych; Boskie pochodzenie pragnienia szczęścia; Chrześcijańska wizja szczęścia. ${ }^{79}$ Warto zauważyć, że treść ta jest wprowadzana w istotnym kontekście antropologicznym, o czym była mowa w niniejszym opracowaniu. Wychowanie do modlitwy reprezentowane jest przez dwie ściśle maryjne treści. Pierwsza z nich: Hymn dziękczynienia Magnificat, prowadzi do realizacji wymagań (uczeń omawia treść hymnu Magnificat) i postaw (okazuje wdzięczność Bogu za otrzymane dobra, uwielbia Boga na wzór Maryi). ${ }^{80}$ Druga treść z zakresu wychowania

\footnotetext{
76 Tamże, 3, A.14; A.14.1-2; A.14.a.

77 Tamie, 3, A.23; A.23.2; A.23.b.

78 Tamże, 3, B.10; B.10.1-2; B.10.a-d.

79 Tamíe, 3, C.1.

${ }_{80}$ Tamże, 3, D.6; D.6.1; D.6.a-b.
} 
do modlitwy nawiązuje do podejmowanego współcześnie w Kościele tematu: Maryja jako Orędowniczka i Pośredniczka lask. Temat ten domaga się, by uczeń charakteryzował postać Maryi - Służebnicy Pańskiej jako wzoru modlitwy chrześcijańskiej, wyjaśniał znaczenie tytułów Maryi dotyczących Jej wstawienniczej roli, a w kontekście postaw, by z ufnością modlił się do Boga przez wstawiennictwo Maryi. ${ }^{81}$ Wreszcie, podobnie jak w poprzednim etapie, w zakresie zadania wychowania do życia we wspólnocie, wśród wymagań stawianych uczniowi wymienia się ukazywanie roli Maryi w historii Polski dla zachowania wolności i tożsamości chrześcijańskiej Polski: hymn Bogurodzica, obrona Jasnej Góry, ogłoszenie Maryi Królową Polski przez króla Jana Kazimierza, odsiecz wiedeńska. ${ }^{82}$

Wreszcie mający bardzo ogólny charakter zapis dotyczący katechezy specjalnej wskazuje, że wśród podstawowych pojęć religijnych winno znaleźć się pojęcie odnoszące się do Maryi ${ }^{83}$.

$* * *$

Katecheza maryjna w sposób oczywisty winna znaleźć poczesne miejsce w przekazie wiary Kościoła w Polsce. Potrzeba, by pozostała ona katechezą ortodoksyjną, a jednocześnie zakorzenioną w liturgii i pobożności. Bowiem nowa ewangelizacja domaga się nie tyle fajerwerków duszpasterskich, choć i one w przypadku młodzieży pełnią jakąś rolę, ale pracy organicznej, związanej z sytuacją uczniów, z pojęciami wiary. Te pojęcia docierają przez przekaz rodzinny, parafialny, przez szkołę i komunikację cyfrową, od której młodzi ludzie bywają uzależnieni. Warto, by planujący katechezę zdawali sobie sprawę z tego problemu i by starali się go rozwiązać. Wiara potrzebuje ciepła, przytulenia się do Serca Matki. „Za każdym razem,

\footnotetext{
81 Tamże, 3, D.7; D.7.1-2; D.7.a.

82 Tami̇e, 3, E.6.3.

83 Tamże, S. A.3.
} 
gdy spoglądamy na Maryję, znów zaczynamy wierzyć w (...) moc czułości i miłości". ${ }^{84}$

Słowa kluczowe: mariologia; katecheza; treść katechezy; katecheza maryjna Keywords: Mariology; catechesis; contents of catechesis; Marian catechesis

\section{Marian Catechesis for Children and School Youth. Sources, Thematic Areas, Rules \\ Summary}

The aim of the article is to show the main challenges facing Polish catechesis, including religious education at school; these challenges relate to the proper approach to the person of the Mother of God in the experience and practice of Catholicism, to appreciate the element of evangelization and identity in the preaching of faith. The author addresses the issue of the relationship between three concepts as follows: catechesis, the school of faith and the school of Mary described in the Bible and through Tradition. Then, the proper approach to Mariology in the context of entire theology it synthetically shown. The summary is a presentation of the mystery of Mary as the content of catechesis and the formulation of postulates related to Marian catechesis.

${ }^{84}$ EG, nr 288. 